\title{
Marxism and Socialist Revolution
}

\author{
GEOFF ELEY
}

\section{Vignette I: Zhu Zhixin}

The first fragments of Karl Marx's writings translated into Chinese (some brief excerpts from the Communist Manifesto) were attached to an article of November 1905 by 22-year-old student Zhu Zhixin (1884-1920) in The People's Journal (Min Bao), which was the organ of the newly formed Revolutionary Alliance (Tongmenghui) of Sun Yat-sen and other exiles in Japan. Zhu followed this introduction to the lives of Marx and Engels (entitled "Short Biographies of German Social Revolutionaries") with a second article on the life of Marx's great rival of the I860s, Ferdinand Lassalle, together with a series of further commentaries on the progress of

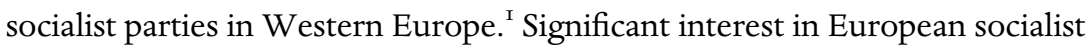
thought, whether among the revolutionary émigrés or radicalized student circles in China itself, seems to have dated from these years. It was a reception almost wholly mediated by translations from Christian socialist and nascently social-democratic publications in Japan, themselves drawing on writings from the United States. Such interest now surged, drawing major impetus from the Russo-Japanese War of 1903-05. ${ }^{2}$ The early understandings were loose and eclectic, taking their cues especially from the history and outlook of German social democracy, but with an interest in far wider bodies of social reforming thought too. ${ }^{3}$ The impact of the 1905 Russian Revolution then

For general perspective I am greatly indebted to Mrinalini Sinha and Julia Adeney Thomas. I See Maurice Meisner, Li Ta-Chao and the Origins of Chinese Marxism (New York: Atheneum, 1979), 52; Martin Bernal, Chinese Socialism to 1907 (Ithaca: Cornell University Press, 1976), 67-68, 107-28.

2 Thus in 1903, the Bookshop published three guides to socialism: Modern Socialism by Fukui Junzō (I899); The Socialist Party by Nishikawa Kōjiro (I90I); and Socialism by Murai Chishi (1899). Bernal, Chinese Socialism to 1907, 94.

3 See Martin Bernal, "The Triumph of Anarchism over Marxism, 1906-1907," in Mary Clabaugh Wright (ed.), China in Revolution: The First Phase, 1900-1913 (New Haven: Yale University Press, I968), IIO-I2. 
decisively shifted the ground of revolutionary thinking in China. Inspiration came again from socialists in Japan, most notably Kōtoko Shōsui (I87I-I9II) who was then turning to anarchist conceptions of direct action, terrorist thinking and the example of the Russian Socialist Revolutionaries (SRs). Henceforth, under Kōtoko's influence, Chinese revolutionaries also turned toward Russia, replacing versions of Marxist-inclined social democracy with varieties of anarchocommunism inspired both by the terrorist strand of SR militancy and by the thought of Peter Kropotkin, whose works Kōtoko was in process of translating. ${ }^{4}$ Between 1906-07 and 1919-20, in other words, Marxism per se receded in China as a distinct body of precepts and theory. As a revolutionary exemplar and source of socialist theory, Marx jostled among much wider intellectual company, from Kropotkin and Bakunin to Saint-Simon, the Fabians and Henry George. Budding socialists cleaved increasingly either to revolutionary violence of anarchist coloration or to the social policy socialisms stressing national welfare and development. Before returning to China from Tokyo in spring 1907, for example, Zhu Zhixin had registered exactly this shift in affiliation, moving from embryonic familiarity with the perspectives of West European social democracy toward the direct-action militancy of anarchism instead. It was only later, very dramatically in the turmoil surrounding the reaction to the Paris Peace Conference in 1919, that revolutionaries turned back toward Marx. ${ }^{5}$

\section{Vignette 2: Nguyen Ai Quoc/Ho Chi Minh}

Acting for the Association of Vietnamese Patriots in France in January 1919, the future Ho Chi Minh (1890-1969), then known as Nguyen Ai Quoc (Nguyen the Patriot) and working since 1917 in the restaurant kitchens of Paris, petitioned the Paris Peace Conference fruitlessly in support of Vietnamese national self-determination. Already a member of the French Socialist Party (SFIO, Section Française de l'Internationale Ouvrière/French Section of the Workers' International), Nguyen/Ho then gave his support to the Third International's Twenty-One Conditions at the Socialists' Tours Congress in December 1920, joining the new French Communist Party (PCF) as a founding member. He moved in late 1923 to Moscow to work for the Comintern. He served there in the leadership of the short-lived Krestintern

4 Ibid., I23-42.

5 See here ibid., I34-42. For the explosion of Marxism around the founding of the Chinese Communist Party, see esp. Arif Dirlik, The Origins of Chinese Communism (New York: Oxford University Press, 1989). 
(Peasant International), and kept up a high level of journalistic activity, while delivering a famous critique of the PCF's neglect of colonial matters from the podium of the Third International's Fifth Congress in June-July 1924. Moving next to China in December 1924, he was attached to the Whampoa Military Academy under Mikhail Borodin in Canton, where he formed the Vietnamese Revolutionary Youth League in June 1925. This became the core of the future Indochinese Communist Party, over whose foundation in February 1930 Nguyen/Ho was to preside. Strikingly, as in the Chinese case, these specifically Marxist, or even socialist, affiliations developed at a very late stage. Nguyen/Ho's most illustrious predecessor, the revolutionary Pan-Asian nationalist intellectual Phan Boi Chau (I867-1940), was exploring socialist ideas only by the early I920s, while the broader nationalist tradition displayed mainly a wide range of nonsocialist constitutionalist, radical-democratic and insurrectionary thinking. Similarly, by having gone west in $1912-18$, rather than following an earlier patriotic generation to China and Japan, Nguyen/Ho was exposed on his early travels to an array of influences where socialism was just one among many - rationalist conceptions of freedom and human perfectibility, universalist ideals of civil liberty and democracy, the pursuit of welfare, the advance of science and technology, progress in the widest Enlightenment sense. ${ }^{6}$ Again, as in China, the turning to Marxism came quite suddenly and late in the day, inspired in 1919-20 by disillusionment with the Paris Peace Conference, the clarifying shock of colonial obduracy and the opening of the communist horizon.

\section{Vignette 3: Manabendra Nath Roy}

Finding himself in Mexico City by July 1917, having left India two years before via the Dutch Indies, Japan, China and the United States, the revolutionary nationalist M. N. Roy (I887-1954) completed his passage from Bengal's insurrectionary Swadeshi Movement to an increasingly self-conscious Marxist outlook. Integrating into Mexico City's left-wing anti-colonial and socialist circles during the culminating stage of the Mexican Revolution, Roy headed the infant Mexican Socialist Party in December 1918 while overseeing its conversion into the communist party next year. Recruited for the Third International's Second Congress by Borodin, then chief Soviet envoy to the Americas, he left Mexico in 1919, reaching Berlin in May 1920 en route for

6 Thomas Hodgkin, Vietnam: The Revolutionary Path (New York: St. Martin's Press, 198I), 22I-22, relying partly on Truong Chinh, President Ho Chi Minh, Beloved Leader of the Vietnamese People (Hanoi: Foreign Languages Publishing House, I966), IO-II. 
Moscow. The terms of his disagreement with Lenin at the Comintern Congress in July then set the terms of debate over "the National and Colonial Question" for the coming decade. If revolution in the capitalist West remained primary (Lenin), communists in the colonial world needed to support "bourgeois-democratic nationalism" against Western colonial rule. But Roy, in contrast, placed the Asian revolution first: just as the imperialist economies rested on the system of colonial extraction, so would "the fate of world Communism [depend] on the triumph of Communism in the East."7 After the Baku Congress of the Peoples of the East in September 1920, Roy was dispatched to Tashkent to organize an Indian Communist Party (CP) and coordinate an anti-British pan-Turkic mobilization, enlisting the nationalist regime in Afghanistan and a revolutionary Muslim "Army of God" aimed toward the Indian Northwest Frontier, where it would connect with the Khilafat movement in India. While the latter fed into the Indian CP's early militancy, the greater ambitions fizzled out, leading to the closure of the Comintern's Central Asian Bureau (the Tashkent School) in May I92I and its replacement by the Moscow Communist University for the Toilers of the East, with Roy as Director. After some time in Berlin and dispatch to China in 1927, Roy was tarred with the debacle of the CP's suppression by the Kuomintang, falling foul of Stalin's ascendancy and being expelled from the Comintern in 1928-29. Most striking in Roy's ten-year passage through communism was the flux of his affiliations - his restless essaying of revolutionary options and probing of metropolitan and colonial exigencies, in a kind of actualized heterodoxy. His career highlights the open-ended and unfinished quality of the global communist movement in its founding years of I9I9-23. The cosmopolitan imaginary of his life between the early I9oos and his final return to India in 1930, reaching across East Asia and the Pacific to the Americas and thence to Berlin, Moscow, Tashkent and Shanghai, was shaped from a "deterritorial" ground of cultural internationalism highly specific to the early twentieth century.

\section{Vignette 4: José Carlos Mariátegui}

When the Peruvian journalist-intellectual José Carlos Mariátegui (I894-1930) was blackmailed into European exile by the freshly installed dictatorship

7 Jon Jacobson, When the Soviet Union Entered World Politics (Berkeley: University of California Press, 1994), 54.

8 See Kris Manjapra, M. N. Roy: Marxism and Colonial Cosmopolitanism (New Delhi: Routledge, 20I0), 3-4 and passim. 
of Augusto Leguía in 1919, he was the feted 25-year-old self-educated editor of the newspaper La Razón launched in 1916. By making La Razón into the uncompromising voice of labor movement and university reform, he rapidly clashed with Leguía, whose reform-mindedness and tolerance for any forthrightly independent radicalism had soon been exceeded. During his European sojourn (lasting until 1923), Mariátegui passed through France, Germany and Austria, before settling in Italy at the height of the biennio rosso (red two years). Already familiar with Marx and enthused for the Bolshevik Revolution and the ideas of Lenin, he luxuriated not only in Europe's revolutionary atmosphere of 1919-23, but in the cultural militancies of modernism too. Henri Barbusse and Georges Sorel were each vital influences. Key interlocutors became Piero Gobetti and Antonio Gramsci, whose weekly newspaper L'Ordine Nuovo (The New Order, 1919-25) became a model for Mariátegui's own Amauta, launched in 1927. ${ }^{9}$ Mariátegui was in Italy during the factory occupations of September 1920; attended the Italian Socialist Party's Livorno Congress in January I92I, when the split occurred that produced the Italian Communist Party (PCI); and left Italy as Benito Mussolini came to power, propelled (in Mariátegui's view) by the left's shying away from revolution. During the I920s his thought showed remarkable scope and originality, ranging across organized and popular religion, education and folk culture, the place and purpose of intellectuals, the importance of the peasantry, the relations among indigeneity, race and national belonging, and the urgency of reconciling the national and the cosmopolitan (including the latter's US and European dimensions), as well as the socialist standbys of economic analysis and political strategy. ${ }^{\text {IO }}$ Yet his impact lacked organized context before the Peruvian Socialist Party was founded in October 1928 (renamed the communist party in 1930), with Mariátegui as general secretary. Comintern contacts dated only from late 1927, and even then Mariátegui guarded the new party's independence. Missing the June 1929 First Meeting of Latin American Communist Parties in Buenos Aires because of illness, he was chided for a range of heterodoxy, whether on the peasantry's progressive

9 Amauta was taken from the Quechuan word for "master" or "wise," the title for teachers educated in the "Houses of Knowledge" in Cuzco under the Inca Empire. Quechuan is the main indigenous language of the Andean region of South America.

Io Mariátegui's principal work (1928) has been translated as Seven Interpretive Essays on Peruvian Reality (Austin: University of Texas Press, 1971). See also Jesús Chavarría, José Carlos Mariátegui and the Rise of Modern Peru, 1890-1930 (Albuquerque: University of New Mexico Press, 1979); Nicola Miller, In the Shadow of the State: Intellectuals and the Quest for National Identity in Twentieth-Century Spanish America (London: Verso, 1999), 67-70, II7-2I, I53-62, 193-95. 
potential, the national belonging of indigenous peoples, the capitalist consequences of imperialism, or the revolutionary priorities for Peruvian society (democratic vs. socialist). Thus during the febrile revolutionary conjuncture of 19I7-23, Mariátegui's relation to communism, too, was creatively expansive and undecided, with little of the dogmatism that later proved so confining.

\section{Revolution as Parliamentary Preponderance}

From the turn of the century, through the cataclysm of World War I and the succeeding revolutionary upheavals, the practical and imaginative contexts for revolution around the globe radically changed. The above four itineraries were emblematic for this larger account. If in each case the intensities of I9I7-23 were decisive in convening new possibilities and radicalizing them, then they also reflected longer accumulations of change, with effects mingling and concentrating inside that immediate conjuncture. Some of those longer-range determinations figured the relentlessly expanding penetration of capitalist relations across the globe since the i850s. Some resulted from the rivalries of world empires since the I880s and their impact on the given colonial system. Others sprang from the European crisis of liberal constitutionalism before I9I4, when the transnational political settlement of the I860s began to come apart, shaken by novel popular-democratic mobilizations centering on the 1905 Russian Revolution. The first stirrings of anti-colonial nationalism also propelled a global revolutionary surge, hitting Russia in 1905, Persia in 1906-07, Turkey in 1908 and China and Mexico in I9II. Under this press, the larger contexts for thinking about socialist change - the complicated global grounds for strategizing revolutionary politics - became ever harder to ignore. After the I89os, the impact of demands for self-government and social progress in the colonial and neocolonial world remade the ground where socialists needed to act and think. The settled reliabilities of socialist politics, whose terms had solidified institutionally and practically inside the national-state frameworks created since the I860s, became broken apart and then recast.

Despite all variation in the patterns of popular-democratic politics, including the regionally significant persistence of anarchism and other nonsocialist traditions, a particular model of working-class politics became normalized across Europe in the last quarter of the nineteenth century, one broadly integrating Marx's arguments from the later I860s and early I870s. "Marxism" by I9I4 stood for many things, but in its prescriptions for the conduct of 
politics it came from these origins. In the First International's founding debates after 1864, Marx assembled a program which, over time, gave the new socialist parties a template. It included the practical agenda of trade union reforms and labor legislation of his "Instructions" for the delegates to the 1866 Geneva Congress; the resolution on public ownership at the Brussels Congress in I868; and the resolution of the London Congress in I87I calling for "the constitution of the working class into a party." Thereto came the negative boundary drawing against older traditions, which Marx devoted so much energy to defeating - liberal-reformist trade union leaders, especially in Britain; French Proudhonists hostile to trade unionism and political action via the state; Mikhail Bakunin and the anarchists, who rejected centralist organizing and the value of party; and the remaining supporters of Auguste Blanqui, with their insurrection hankerings and conspiratorial methods. As the central socialist desideratum, Marx proposed the independent mass party of labor. By the political standards of the time, this was a new departure.

It was vitally keyed to surrounding political transformations of the I860s. In a new drama of constitution-making, Italy and Germany appeared on the map as unitary states for the first time. After the long hiatus of the reactionary I850s, labor movements reemerged, including the craft unions of the Trades Union Congress in Britain and workers' associations in the various states of Germany. Labor organizing spread geographically across the continent in the first great European strike wave of I868-74, aided by liberalizing economic legislation and constitutional reforms, country by country. Popular democracy made a spectacular appearance in the Paris Commune of 187I. What excited Marx in all of this was not just the return of open class conflict, but its palpable connections to politics, offering new openings which the First International then sought to shape. Vital to labor's revival, Marx thought, was the changing constitutional context that enabled it. As a result of the I860s, liberal constitutionalism gained lasting ascendancy across Europe as a whole, becoming normative for the coming four decades. For the first time, it legalized labor movement activity on a national scale at the level of the state.

This duality, between a new understanding of socialist strategy based on the party and the new type of liberal-constitutional polity enabling it to function, decisively framed the socialist mainstream until the new challenges of the pre-I9I4 decade. In most of Europe the dominant left vehicle became a national social-democratic party in conjunction with nationally federated trade unions, in a new practice that was centralist, stressing national rather 
than local forms of action; parliamentarist, privileging the parliamentary arena as the source of sovereignty; and constitutionalist in the given meanings of the term, adopting representative over direct means of governing. This preference for centralized forms over the looser federated ones of the I820s to I860s made the party into a new theme of left political discourse, with every European country acquiring its national social-democratic party. ${ }^{\mathrm{II}}$

By the mid I89os, the rise of labor movements in Europe had reached a watershed. The main cycle of party foundations was complete, covering Central, Northern and Western Europe; and the next phase was under way, proceeding from Poland and the Balkans in the early I89os through the Russian Empire to its completion by 1905. The opening of a period of economic expansion after I895-96 also brought the first period of sustained unionization in Europe. The socialist parties of the first cycle now made steady electoral gains, establishing a parliamentary presence, permeating the public sphere, and deepening their local roots. In the prelude to World War I, those parties experienced a remarkable upswing in electoral success, so that by I9I4 seven commanded at least a quarter of their national electorates those in Finland (43 percent, I913), Sweden (36.5 percent, 1913), Germany (34.8 percent, 1912), Czech lands (32.2 percent, I9II), Denmark (29.6 percent, 1913), Norway (26.3 percent, I9I2) and Austria (25.4 percent, I9II). ${ }^{\mathrm{I2}}$ This north-central European "social-democratic core" revealed a common pattern: single socialist parties organizationally united but ideologically diverse, without serious rivals, and rallying heterogeneous interests around broadly social-democratic values. But elsewhere, matters were more divided. In Britain, locally vigorous socialist initiatives could make small headway against the resilience of a popular liberalism shaped in the I86os. In Italy and Spain, socialists contended with acute regional disparities, state violence and strong urban anarchist movements. In France, socialists were notoriously fractious, identifying with rival revolutionary traditions, conserving earlier non-Marxist legacies and taking contrasting lessons from the Paris Commune; only in 1905 was that sectarianism overcome, when the Marxist followers of Jules Guesdes joined with the ethical socialism of Jean Jaurès to form the SFIO as a parliamentary party comparable to those elsewhere, recording 16.8 percent of the popular vote in I9I4.

II For a full tabulation, see Geoff Eley, Forging Democracy: The History of the Left in Europe, 1850-2000 (New York: Oxford University Press, 2002), 63.

I2 For complete tabulation, ibid., 66-69. Four other parties surpassed the 20 percent barrier: the Italian (22.8 percent, 1913), Belgian (22.5 percent, 1900), Bulgarian (20.2 percent) and Swiss (20.9 percent, I913), while the Dutch party reached I8.6 percent (I913). 
A crucial source of socialist strength was the party's all-embracing mass base. Between the First International and the self-confident growth accompanying the Second International after 1889 , socialists essentially invented the modern political party. The new model of a permanent campaigning organization geared to the fighting of elections now presumed building a continuous presence on the ground, linked to the supporters' everyday social lives. Using the architecture and rhythms of workplace, neighborhood and family, socialists were able to shape collective solidarities with continuity over time, bound together by elaborate machineries of identification. By these means the growing parliamentary strength became connected to a wider coalescence in society. If a special relationship was welded to the consequences of capitalist industrialization, in a compelling narrative of capitalist crisis and the projected socialist future focused on the industrial working class, then socialist support was actually far broader. Sociologically, the appeal was highly ecumenical. Socialists not only spoke across the multiform interests and attitudes separating different categories of workers (whether manual laborers in mining, manufacture, transportation and construction, or clerks, shop assistants, uniformed workers, servants and so forth), but appealed to other popular classes like the peasantry and petty bourgeoisie as well, and even the lower professions and intelligentsia. Socialism's strength before I9I4 was this ability to weave the myriad workingclass experiences of societies undergoing rapid transformation into a single story sufficiently inspiring to gather in many other hopes for a better world too.

This imposing machinery of identification and the apparently inexorable progress of socialist parties as popular movements made the "forward march of labor" seem inevitable. ${ }^{\mathrm{I} 3}$ If far from homogeneous, working people acquired compelling reasons for seeing themselves as a cohesive class, because their patent powerlessness in society made the ballot box so disproportionately valuable, especially as their other collective resource, workplace combination in unions, remained elusive in most countries until the upheavals of 1910-20. In that sense, the suffrage struggles of I890-1914 were the engine of political class formation: the Belgian constitution of 1893; universal manhood suffrage in Austria in 1907 and Italy in 1912; Scandinavian liberalizations in Norway (I898), Denmark (190I), Finland

I3 Compare the young Eric Hobsbawm's early anthology, Labour's Turning Point 1880-1900 [1948], 2nd edn. (Hassocks: Harvester Press, 1974), with the later stock-taking in his coauthored The Forward March of Labour Halted?, ed. Martin Jacques and Francis Mulhern (London: Verso/Marxism Today, 198I). 
(1905) and Sweden (1907); recurring suffrage mobilizations in Germany, especially in 1905-06 and I909-I0. Once workers acquired the vote, it was plain, they also used it, as the remarkable pan-European surge of electoralism in I907-I4 showed. For the pre-I9I4 socialist parties, using the available parliamentary forms had become axiomatic, whether as a platform for mobilizing the masses or for the winning of short-term reforms. Moreover, this socialist parliamentarianism was shaped around a political imaginary that was national in character. The growing masses of workers joining the pre-I9I4 socialist parties may well have been fervently internationalist. But the "politically defined nation" had become "the effective framework of their class consciousness." ${ }^{24}$

\section{Revolution and Reform Under the Second International}

In the debates surrounding the First International the arguments for different types of state organization and different types of labor movement were homologous, contrasting once again with what went before. Until the I860s, the locally based associational activism of radical democrats and early socialists had coalesced mainly around certain common ideals, focused by newspapers, pamphlets, itinerant lecturers and a few national parliamentarians and other charismatic figures. By the last quarter of the nineteenth century, the very different outlook of the new social democracy now showed analogous convergence around movement and state, with the character of the future socialist constitution being abstracted from socialists' organizational experience under capitalism. Thus, rather than the forms of direct democracy that gave greater decision-making to the rank and file at the local level and on the shop floor, both socialist parties and unions decisively chose representative forms of national organization; a preference repeated in the parliamentary type of constitution. Likewise, if centralized bureaucracy concentrated the movement's strengths and equalized resources among its stronger and weaker sections, then by the same logic central planning would give the state of the future maximum resources for building socialism.

So far, this was also consistent with what Marx thought in the I860s and I870s about revolutionary strategy: Working-class emancipation was above all a political question; it required a class-based socialist party; that party was to concentrate the workers' collective strengths in a centrally directed national

I4 Eric J. Hobsbawm, The Age of Empire 1875-1914 (New York: Pantheon Books, 1987), I29. 
movement capable of challenging the ruling class. But here discrepancies arose. Marx viewed the existing state as an institutional complex that operated in the interests of capital and for the maintenance of class rule; it could not just be taken over but had to be destroyed. On this score, the later social democrats evinced no such clarity. They either deferred questions associated with the revolutionary assumption of power or backed away from revolution altogether. ${ }^{15}$

This was another vital transition. If a broad agenda of democracy and social reform was the task of the independent parties of labor Marx had advocated, free from bourgeois tutelage or association, then the revolutionary entailments were not thought through but consigned to a still to be specified future. Inside that indeterminacy, until the I89os, socialists still harbored apocalyptic hopes, imagining the inevitability of revolution via earlier nineteenth-century precedents, where social crises led to rapid breakdowns of authority and popular insurrections. Blanqui epitomized such revolutionary psychology, which Marx also shared before the tragedy of the Commune finally fixed his hopes on laws of capitalist development and objective processes of the class struggle. Revolutionary expectations were further fueled by police repression, threats of illegality and concomitant antisocialist activity, exemplified in the drama of the German Anti-Socialist Law of 1878-90. For August Bebel, a towering personality of the Second International, the Kladderadatsch or great collapse of the system was always around the next corner. ${ }^{16}$ In place of collapse, however, increasingly came inclusion. By 1900, socialist parties were themselves becoming strong enough to join the "bourgeois" political constellation, winning seats in national elections, participating in parliamentary culture and campaigning for reform. For parties of revolutionaries, accordingly, questions of purity or compromise, maximalism or constructive participation, revolution or reform, increasingly besieged the agenda.

I5 Marx himself never developed his thoughts on the subject systematically. In the event of a revolution, he envisaged a transitional state authority, a "dictatorship of the proletariat," taking decisive and even repressive measures if needed to ensure the revolution's immediate survival. But he used that term as a general synonym for the democratic rule of the working class, as the overwhelming majority of the population, over the rest of society. See Richard N. Hunt, The Political Ideas of Marx and Engels, vol. II, Classical Marxism, 1850-1895 (Pittsburgh: University of Pittsburgh Press, 1984), esp. 363-67; George Lichtheim, Marxism: An Historical and Critical Study (London: Routledge \& Kegan Paul, 196I), I28; Monty Johnstone, "Marx, Blanqui, and Majority Rule," in Ralph Miliband and John Saville (eds.), The Socialist Register 1983 (London: Merlin, 1983), 296-318.

I6 Vernon Lidtke, The Outlawed Party: Social Democracy in Germany, 1878-1890 (Princeton: Princeton University Press, 1966), 233. 
Controversy erupted over these questions at the close of the Second International's first decade, prompted in I899-I900 by two instances of "ministerialism." I7 In the so-called Millerand affair at the height of the Dreyfus crisis in I899, a leading Independent Socialist, Alexandre Millerand (I859-1943), joined a French government of Republican Defense as minister of commerce, thereby polarizing reactions among French socialists and their comrades elsewhere. With the shooting of three strikers in a dispute at Chalon-sur-Saône, their worst predictions seemed confirmed. As Jules Guesde (I845-I922) said, "the war on the working class has never been so implacable as under the Waldeck-Rousseau-Millerand government." ${ }^{\text {,I8 }}$ Yet for Guesde's main rival in the French movement Jean Jaurès (I859-I9I4), on the other hand, it was less socialist advocacy per se that demanded priority than the abstract and ethical defense of French liberties at a time when the republic was in danger.

The scandal dominated the International's Fourth Congress in Paris in September 1900, when the SPD wielded its crossnational authority. Wilhelm Liebknecht's first reaction was peremptory: “[A] socialist who enters a bourgeois ministry either deserts to the enemy, or he surrenders to the enemy."' ${ }^{\prime 9}$ But this then gave way to the revolutionary pragmatics of Karl Kautsky (I854-1938), by now the officially credentialed voice of Marxist theory: Providing democratic rights were upheld as a good in themselves, tactical alliances might certainly be approved. To see nonsocialist forces as "one reactionary mass" (in the old Lassallean slogan) was profoundly misconceived, especially as socialists grew stronger, "already powerful enough to influence the course of events, but not strong enough to be the dominant power."20

The clearest case for coalition, Kautsky argued, was a national emergency, when a society's "fundamental democratic institutions" were in danger. ${ }^{2 \mathrm{I}}$

I7 The Second International convened in Paris in July I889, at a congress initiated by the SPD with 39I recognized delegates from twenty separate countries, presenting the Marxist face of Europe's emergent socialist parties. Congresses met subsequently in Brussels (I89I), Zurich (I893), London (I896), Paris (I900), Amsterdam (1904), Stuttgart (1907), Copenhagen (I9I0) and Basle (I9I2). From I900, a permanent Secretariat sat in Brussels, with an International Socialist Bureau (ISB) to coordinate Congress resolutions.

I8 Robert Gildea, Barricades and Borders: Europe 1800-1914 (Oxford: Oxford University Press, 1987), 400.

I9 See Wilhelm Liebknecht to the Parti ouvrier français, Io Aug. I899, in Institut für Marxismus-Leninismus (ed.), Dokumente und Materialen zur Geschichte der deutschen Arbeiterbewegung, vol. IV (East Berlin: Akadamie Verlag, I967), 3I-32.

20 Karl Kautsky to Victor Adler, 5 May I894, in Friedrich Adler (ed.), Victor Adler: Briefwechsel mit August Bebel und Karl Kautsky (Vienna: Wiener Volksbuchhandlung, I954), I52.

2I Ibid., II6. 
In the second instance of ministerialism, an Italian political crisis seemed to meet exactly this criterion. The right-wing government of General Luigi Pelloux, formed after a May 1898 massacre of demonstrators in Milan, unleashed draconian repression against the left, imposed by royal decree. In response, liberals under Giovanni Giolitti and Giuseppe Zanardelli formed a common front with the extreme left. This emerged from elections with big gains, eventually forming a new government in February I90I, endorsed by the Italian Socialist Party (PSI). The Millerand scenario repeated itself. Filippo Turati (I857-1932) pushed social reforms, including a labor office, social insurance, protective laws against female and child labor, and public works. Likewise, however, in defending the constitution Giolitti still used troops against strikers, rapidly exposing the limits of this progressive front. Significantly, in contrast with Millerand, Turati had refused ministerial office as such, and the PSI eventually abandoned the government, thereby preserving the purist protocol. ${ }^{22}$

Thus the scandal over "ministerialism" revealed two models of socialist politics, whose tensions were to recur. The dilemmas were posed inside the SPD by the contemporaneous "revisionist controversy." If by 1900 the SPD was the strongest of Europe's socialist parties and its Erfurt Program the model of its kind, then Kautsky, the latter's architect, was the most prestigious theorist. ${ }^{23}$ His commentary on the program, The Class Struggle, a "catechism of social democracy," was translated into sixteen languages by 19I4, and other Marxists deferred to his views. While building an increasingly elaborate organization and implanting itself in the national polity (becoming by 1898 the largest German party in popular votes), moreover, the SPD remained explicitly revolutionary: Its goal was nothing less than "the overthrow of capitalist society." 24 As it advanced in parliamentary strength, though, its revolutionary purity became a problem, for while consistently declaring its apartness from bourgeois society, the party was drawn willy-nilly into the "system." Into this developing gap between revolutionary theory and immediate practice came a series of articles by the SPD's veteran intellectual, Eduard Bernstein, published in its premier journal, Kautsky's Neue Zeit, and

22 James Joll, The Second International 1889-1914 (New York: Routledge, 1966), 95.

23 Adopted in I89I, the Erfurt Program became a template for the Norwegian (I89I), Swiss (I893), Belgian (I894), Dutch (I894), Swedish (I897) and East European party programs, while the contemporaneous Czech (I888), Austrian (I889) and Hungarian programs (1890) followed similar lines.

24 This was Liebknecht's peroration to the SPD's I898 Congress. See Raymond H. Dominick III, Wilhelm Liebknecht and the Founding of the German Social Democratic Party (Chapel Hill: University of North Carolina Press, I982), 399. 
collected as The Preconditions of Socialism and the Tasks of Social Democracy. There Bernstein argued that capitalism had surmounted its tendency toward crisis. The Marxist doctrine of pauperization - ever-widening polarization between rich and poor, inscribed in the labor theory of value - was falsified by modestly improving standards of living. Working-class movements could hope to win reforms under capitalism after all, gradually moving the state toward democracy. Against the catastrophic theory of revolutionary transition, Bernstein proposed a continuous model of improvement, an "evolutionary socialism." 25

In response, a storm of disagreement came forth, a chorus of orthodox and radical Marxists, Rosa Luxemburg (I87I-I9I9) prominent among them. After some hesitancy, incited by Bebel, Kautsky also joined the fray, and at the SPD’s I899 Hanover Congress Bernstein was officially disavowed. As with the response to Millerand, the real fight was over strategy: Bernstein's critique of Marxist economics mattered less than his political conclusions. If "[the] peasants do not sink; [the] middle class does not disappear; crises do not grow ever larger; [and] misery and serfdom do not increase," then socialists should recruit nonproletarian supporters and make alliances with liberals and other nonsocialist progressives. ${ }^{26}$ Indeed, the SPD's future lay precisely in the coalition-building advocated by Turati in Italy, Jaurès in France, or the Fabians in Britain. But Bernstein misread the emotional attachment to revolutionary rhetoric and the party's heritage - both the integrative power of the SPD's revolutionary ethos and the heroic myth of its persecution under the Anti-Socialist Law, not to speak of the actual impediments against reform from the imperial state's continuing anti-democratic intransigence.

Defeating revisionism inspired a powerful rallying of orthodoxy in the SPD, in fact, which hugely constrained coalition-building well into the future. For in Kautsky's treatment this was always a zero-sum game: The primacy of the class struggle precluded alliance with bourgeois parties and vice versa. The alignments around this question in the Second International reflected Europe's map of constitutionalist progress: Those condemning reformism came from countries with weak parliamentary constitutions; their opponents and the abstainers from those where democracy was strong. This already presaged the constellation of I9I4-I7 too, as the vocal critics of revisionism in

25 Henry Tudor and J. M. Tudor (eds.), Marxism and Social Democracy: The Revisionist Debate 1896-1898 (Cambridge: Cambridge University Press, I988), I68-69.

26 Peter Gay, The Dilemma of Democratic Socialism: Eduard Bernstein's Challenge to Marx (New York: Columbia University Press, 1952), 250. 
the Amsterdam debate of 1904 numbered several who were later to join the wartime revolutionary opposition - Khristian Rakovsky (I873-194I) of Bulgaria, Rosa Luxemburg, and of course Vladimir Ilich Lenin (I870-1924) from Russia. ${ }^{27}$ While the Amsterdam debates helped drive the French unification into the SFIO, therefore, its main longer-term effects were divisive, along faultlines becoming ever-clearer during the prewar years. And the impetus in that regard came from the global impingement of imperialism.

Significantly, colonialism first came onto the International's agenda at Paris in 1900 during the Boer War, British imperialism's assault on a white settler republic. For neither the exploitation of indigenous peoples in Africa and Asia nor East European nationality questions ever troubled the International's surface until 1907. Nor did the new critiques of imperialism, like Rudolf Hilferding's Finance Capital and Rosa Luxemburg's Accumulation of Capital, say very much about the colonial world per se, as against the dynamics of metropolitan capitalist crisis. In the light of colonial violence, the Stuttgart Congress in 1907 did condemn "capitalist colonial policies [which] must, by their nature, give rise to servitude, forced labor and the extermination of the native peoples." ${ }^{38}$ This debate had a familiar look, with revisionists calling again for flexibility: Bernstein and his fellow SPD reformist Eduard David (1863-1930), the Dutch SDAP's Henri van Kol (I852-1925) and the British Labour Party's Ramsay MacDonald (I866-1937) on one side; Kautsky, SPD leftist Georg Ledebour (I850-1947), the Guesdist AlexandreMarie Desrousseaux (I86I-I955), the Pole Julian Marchlewski (I866-I925) and the British Social Democratic Federation's Harry Quelch (I858-1913) on the other. ${ }^{29}$

Socialists found various ways of accommodating to imperialism. It promoted employment, especially in shipyards, docking, armaments and industries dependent on colonial trade and production, while colonial trade boosted general prosperity. And while positive enthusiasm for "colonialism" among socialists was far rarer, assumptions of racial superiority and acceptance of the "civilizing mission" were not. More seriously, escalating great-

27 See Internationaler Sozialisten-Kongress zu Amsterdam, 14. bis 20. August 1904 (Berlin: Buchhandlung Vorwärts, 1904), 3I-49, in Kongress-Protokolle der Zweiten Internationale. Band 1: Paris 1889 - Amsterdam 1904 (Glashütten im Taunus: Auvermann, 1975).

28 Julius Braunthal, History of the International, vol. I, 1864-1914 (London: Gollancz, I966), 3I8-I9.

29 See esp. Preben Karrsholm, "The South African War and the Response of the International Socialist Community to Imperialism Between I896 and 1908," in Frits van Holthoon and Marcel van der Linden (eds.), Internationalism in the Labour Movement 1830-1940, vol. I (Leiden: Brill, I988), 42-67. 
power tensions fed popular patriotism, especially via fears of foreign invasion and national emergencies. Tsarism was a synonym for reactionary backwardness in the European left's collective imagination, and even Kautsky talked of defending German civilization against possible Russian attack. French socialists saw analogous contrasts between French revolutionary traditions and German militarism and authoritarianism, so that when the SPD blocked SFIO anti-militarist initiatives in the International after 1905, relations became seriously frayed. In fact, the issue of preventing war became the vital test of the International's cohesion. If war was to be stopped, armies, munitions and railways had to be immobilized in all combatant countries, and from 1904 calls for a general strike against war never left the agenda.

If socialists proved susceptible to the strength of superordinate national loyalties in the decade before 1914, habituating themselves to the normalizing rhythms and practicalities of living inside the nation, they could also be correspondingly negligent of national minorities. This was not invariably true - Scottish and Welsh radicalisms had a decisive role in shaping the British labor movement, for instance, while social democracies of the subject nationalities of the Russian Empire paralleled the central Russian party amicably before I9I4. Yet, the SPD had a poor record of either integrating the German Poles or honoring their separate organizations. And a still more stringent test came from the chaos of allegiances in the Habsburg Empire, where the dominant Germans and Hungarians were only the largest national minorities among many.

Thus when the outbreak of war in August I9I4 threw the Second International into disarray, it was not just anti-militarism that was in ruins, but the classical socialist approach to the national question as well. Marxist theoreticians, from Kautsky to Luxemburg, Trotsky to Lenin, had long argued the primacy of internationalism, whether as developmental logic or highest political good: With the maturity of capitalism and the growth of class-consciousness, they believed, workers' national loyalties would surely wither away. Yet, the twenty years before I9I4 told to the contrary - in the popular mobilizations around national crises like the Dreyfus affair, or in the tensions and resentments dividing multinational movements like the Austrian and Czech. Socialist leaderships came tacitly to accept the salience of national loyalties too, from Bebel and Jaurès in their different ways to the practicing reformists increasingly running the trade union and party machines. Some right-wing socialists openly and aggressively declared their patriotism. But in most official declarations there was more commonly silence. No congress of the Second International ever placed the "national 
question" as such onto its agenda. This was what World War I brutally changed, practically overnight.

\section{Revolution as a Non-National and Deterritorial Space}

In their programmatic vision of social transformation deriving from the experience of Europe's capitalist industrialization, Marxists of the Second International approached revolution as the necessary consequence of the inevitable capitalist crisis. The locus classicus for this operative understanding, the textual authority guiding social democrats in their practical relationship to this fervently desired but structurally determined socialist future, was certainly the SPD's Erfurt Program and its derivatives, along with Kautsky's commentary in The Class Struggle. In Kautsky's neo-Darwinian conception of society and its laws of development, the revolutionary opening to the future was inscribed in the necessary movement of history.

As the main motor of change under capitalism, class conflict in these terms was for Kautsky structural and endemic, a permanent and irreducible feature of social life under capitalism. This structural antagonism led to struggles over the social distribution of the value produced in the economy, which assigned people "into two great camps, into two great classes facing each other: bourgeoisie and proletariat." ${ }^{30}$ Under deteriorating conditions of capitalist accumulation and profitability, workers' collective mobilizations, organized through their trade unions and the socialist party, relayed pressures to the political system that created openings for change. The most extreme form of such a breakthrough, a crisis of particular and escalating severity, was revolution.

Given these assumptions about general proletarianization and the associated immiseration thesis, it was not hard to work this expectation of capitalist crisis into a political narrative of the unstoppable working-class majority. Once thoroughly distributed and embedded in economy and civil society, it was believed, the workers' democratic preponderance would be brought to final fruition by means of universal suffrage, civil freedoms and maximal parliamentary forms. A barricades revolution on the style of 1848 was certainly unworkable, so power could only come via the ballot box, whatever confrontations might be needed along the way to deal with ruling-

30 Karl Marx and Friedrich Engels, The Communist Manifesto: A Modern Edition, introd. Eric Hobsbawm (London: Verso, I998), 35. 
class violence, a coup against the constitution, or efforts at suppressing the suffrage. ${ }^{31}$ But absent the climacteric of capitalism's general crisis, this image of the revolution was never put to the test before I9I4. On the one hand, socialists embraced a practical logic of integration. Yet, on the other hand, with barely a third of their national electorates, even the strongest socialist parties had no prospects of actually forming a government. They dwelled in a kind of limbo: Fixed in opposition, they were permanently on the outside; but access to power could only come from coalition, behind an avowedly limited program, by compromising on the ultimate revolutionary goal. ${ }^{32}$

The resulting dilemma sharpened after 1905, when the settlements of the I86os finally came apart. In the wake of the revolution in Russia, with strike waves and suffrage mobilizations elsewhere, Europe's socialist parties faced an unruly revival of extra-parliamentary revolutionism. A new industrial militancy stressing direct action and the futility of parliamentary involvement aggressively outstepped the available social-democratic frameworks and disparaged the state per se, disputing its openness for capture. The scale was immense: After the initial takeoff into mass unionism at the turn of the century, a pan-European strike wave began a widening of labor unrest in 1904-07 that in I9I0-I3 was aggressively continued; if we add the mobilizations accompanying the end of the war, the years I9Io-2o become the great age of European unionization, unmatched until after 1945. Under such challenges - along with women's suffrage movements, nationality questions, the international arms race - conventional political alignments came under intense strain. By I9I3-I4, Europe's parliamentary polities were sliding into chaos - with ten separate ministries in France during 1909-I4, for example, and five Italian governments in only four years. In each respect, parliamentary and trade union, popular politics outgrew the patiently cultivated frameworks of action: Socialist revolution was exceeding its given containers. Not only the constitutionalist frameworks of the I86os were breaking down, in other words; socialist parliamentarianism was too.

The revolutionary years after 1917 showed this in many particular ways. ${ }^{33}$ Most vital was the break from heavily deterministic conceptions of

3I The classic warranty of this argument during the Second International was Engels's new Introduction to the I895 edition of Karl Marx's The Class Struggles in France, 1848-1850 (Moscow: Progress Publishers, 1968), 5-26, which in its published form at the time became tendentiously excerpted by the SPD.

32 For a brilliant explication of this dilemma, see Adam Przeworski, "Social Democracy as a Historical Phenomenon,” New Left Review, I, I22 (July-Aug. 1980), 27-58.

33 Space and the terms of this chapter preclude a detailed discussion. But see Eley, Forging Democracy, I23-233. 
revolutionary crisis and transition. Against that revolutionary fatalism a waiting on history, an automatic Marxism - the revolutionaries of 1917-23 acted from voluntarist exuberance, a conviction in what Georg Lukács called "the actuality of the revolution," a commitment to making the revolution, rather than waiting for it to happen. ${ }^{34}$ This was what Antonio Gramsci meant by the "Revolution against Capital," an escape not just from the prison of capitalist society, but from excessively economistic ways of understanding it too. ${ }^{35}$ Revolutionary preparedness became less an ability to read the movements of the economy than the attainment of revolutionary consciousness. Minds were to be revolutionized. At the outer edge of this new voluntarist revolutionism, the new militants rejected democratic proceduralism, parliaments and parties altogether. "So away with professional leaders, with all organizations that can only work with leaders at the helm," one revolutionist declaimed. "Away with centralism, the organizational principle of the ruling class. Away with all central bodies." 36

The revolutionary turbulence of those years ripped a huge gap in the long accustomed patterns of political practice, through which popular activism of unprecedented scale and intensity could then rush. This comprehensive political restructuring opened a new space of citizenship and recognition, whether via democratic enfranchisement, the political rights of women, or national self-determination. In the process, many of the Second International's failings and omissions were made far more visible than before. But if we broaden the optic still further, by moving away from the European metropole, the greatest effects will emerge in the revolution's worldwide translation: in the remapping of the revolution's possibilities into a newly global political imaginary.

Measured by the Second International's leading activists, within a Eurocentric notation, socialist culture had been nothing if not internationalist. Moreover, the global migrancy of the years before 19I4, which brought vast numbers of people across the Atlantic to the Americas and from Britain to its white settler colonies, created particular global circuits for socialist activists, influences and ideas, especially where transnational labor markets were involved. Socialist activists and union militants took their experiences

34 Georg Lukács, Lenin: A Study in the Unity of His Thought (London: New Left Books, I970), 9-I3.

35 Antonio Gramsci, "The Revolution Against Capital” (24 Dec. 1917), in Antonio Gramsci, Selections from Political Writings 1910-1920 (London: Lawrence \& Wishart, 1977), 34.

36 Anonymous, "Erlebnisse und Schlußfolgerungen eines Revolutionärs," Proletarische Zeitgeist Iо (I93I), cited by Manfred Bock, Geschichte des "linken Radikalismus" in Deutschland. Ein Versuch (Frankfurt am Main: Suhrkamp, I976), 97. 
and skills from most parts of Europe to the Americas just as they did from Britain to Australia, New Zealand and South Africa. ${ }^{37}$ These and other emblematic biographies signified "a genuine international community ... a body of men and women conscious of being engaged on the same historical task, across national and political differences." 38

Yet, this international community remained Eurocentrically self-limiting, halting at the borders of empire. Europe's socialists acknowledged the relevance of democracy for the colonial world only very exceptionally before I9I4: Not only were non-Western voices and peoples of color almost entirely absent from the Second International's counsels, but its parties seldom condemned colonial policy and even positively endorsed it. ${ }^{39}$ Socialists commonly affirmed the progressive value of the "civilizing mission" for the underdeveloped world, while embracing the material advantages of jobs, plentiful food, cheaper goods and guaranteed markets brought by colonialism to the metropolitan home. ${ }^{40}$ Critical insights into the pervasiveness of imperialist culture were rare indeed, from assumptions about racial hierarchies to genocidal practices and acceptance of colonial violence. ${ }^{4 \mathrm{I}}$ Here, the spectacular early twentieth-century stirrings of colonial revolt leveled a powerful rebuke against Europe's left, so that Lenin's readiness in I9I6-I7

37 See for example the essays of Jonathan Hyslop: "A Ragged Trousered Philanthropist and the Empire: Robert Tressell in South Africa," History Workshop Journal 5I (Spring 200I), 65-86; "The World Voyage of James Keir Hardie: Indian Nationalism, Zulu Insurgency, and the British Labour Diaspora 1907-1908," Journal of Global History I, 3 (Nov. 2006), 343-62; "The Imperial Working Class Makes Itself 'White': White Labourism in Britain, Australia and South Africa Before the First World War," Journal of Historical Sociology I2, 4 (Dec. 1999), 398-42I.

38 Eric Hobsbawm, "Preface," in Georges Haupt, Aspects of International Socialism 1871-1914 (Cambridge: Cambridge University Press, I986), xi.

39 The non-European presence in the Second International was confined to the United States, the white settler colonies of Australasia and South Africa, and Japan.

40 This was the argument about "social imperialism" developed by Lenin around the idea of "imperialist super profits" in his writings during the war. See Vladimir I. Lenin, Imperialism, the Highest Stage of Capitalism (New York: International Publishers, 1939), originally published in 1916. For pre-19I4 socialist thinking, see Hans-Christoph Schröder, Sozialistische Imperialismusdeutung. Studien zu ihrer Geschichte (Göttingen: Vandehoeck \& Ruprecht, I973).

4I The detailed picture, country by country, was far more complicated. For Britain, see esp. Stephen Howe, Anticolonialism in British Politics: The Left and the End of Empire, 1918-1964 (Oxford: Oxford University Press, 1993), and Nicholas Owen, The British Left and India: Metropolitan Anti-Imperialism, 1885-1947 (Oxford: Oxford University Press, 2007), I-I35; for Germany, John Phillip Short, Magic Lantern Empire: Colonialism and Society in Germany (Ithaca: Cornell University Press, 2012), I08-59. For the response of SPD revisionists, see Roger Fletcher, Revisionism and Empire: Socialist Imperialism in Germany, 1897-1914 (London: George Allen \& Unwin, 1984). More generally, Robert J. C. Young, Postcolonialism: An Historical Introduction (Oxford: Blackwell, 200I), 7I-I57, and for a helpful conspectus of the years before I9I4, ibid., II5-26. 
to extend the principle of national self-determination to the colonial world marked an audaciously novel departure. In that light, the presence of nonWestern delegates was an especially vital feature of the Communist International's founding Congress in March 1919, as was its backing for anticolonial nationalisms. Moreover, this principled and ringing advocacy of the Bolsheviks for the rights of colonial peoples pointedly highlighted the militant disdain of the Peace Conference that was meeting concurrently in Paris, as the Vietnamese, Chinese, Indian and other non-Western petitioners were only too painfully discovering. ${ }^{42}$

The initial call to the founding Congress of the Third International on 24 January 1919 mentioned thirty-nine groups in thirty-one separate countries, all of them European except for the United States, Australia and Japan. Thus far, little had apparently changed. But other groups from the colonial world were then added, so that the fifty-two delegates converging on Moscow on 2-6 March 1919 (from thirty-five organizations in twenty-two countries) gave a far more interesting picture. What this assembly actually represented, of course, was still unclear.

Aside from the existing communist parties in Germany and Hungary, Europe beyond the former Russian Empire was represented by small leftwing sects or nascent groupings with little evident working-class support or standing, sometimes taking the name, but not especially "communist" in the terms soon to be understood. Most delegates came either from former imperial territories already boasting communist parties of their own - these were in Finland, Estonia, Latvia, Lithuania, Belorussia, Poland, Ukraine, Armenia - or from overlapping and contiguous regions of the Middle East, Central Asia and East Asia. Radical nationalists carrying the torch of anticolonial independence came from Turkestan, Azerbaijan, the Volga Germans, the United Group of the Eastern Peoples of Russia, Turkey, Persia, China and Korea.

Here is where my argument began. With its deliberate appeal to the world's oppressed and exploited peoples, whether under direct colonial

42 See Erez Manela, The Wilsonian Moment: Self-Determination and the International Origins of Anti-Colonial Nationalism (New York: Oxford University Press, 2007); and for a corrective, Pankaj Mishra, From the Ruins of Empire: The Revolt Against the West and the Remaking of Asia (New York: Picador, 20I2); Ali Raza, Franziska Roy and Benjamin Zachariah (eds.), The Internationalist Moment: South Asia, Worlds, and World Views, 1917-39 (New Delhi: Sage, 20I4); Rebecca E. Karl, Staging the World: Chinese Nationalism at the Turn of the Twentieth Century (Durham, NC: Duke University Press, 2002). Arno J. Mayer, Wilson vs. Lenin: Political Origins of the New Diplomacy, 1917-1918 (New York: World, I964), provides the best introduction; also Jacobson, When the Soviet Union Entered World Politics. 
rule or subject to variable metropolitan domination, the Bolshevik Revolution entered a world already in motion. Turkey, Persia, China, Mexico - these were the scenes of existing extra-European upheaval, where older state forms, invariably mined by imperialist penetration, were crumbling before nascent nationalist challenge. The Comintern Congress met against a backdrop of anti-colonial insurgency stretching from Egypt all across Asia, usually aimed against Britain: protests in Cairo against martial law and suppression of the newly founded Wafd Party (March); the Amritsar massacre in India's Punjab (April); the Third Anglo-Afghan War securing Afghanistan's independence (May-June); Mustafa Kemal's nationalist uprising in Anatolian Turkey, along with the Kurdish revolt in Mosul (May); the Syrian General Congress in Damascus, in this case aimed against France (May I9I9-July 1920); continuing rebellion of Tatars, Bashkirs, Kazakhs, Azerbaijanis and other Muslim peoples in former Russian Central Asia; and last but not least, the May Fourth Movement in China exploding against the refusal of the Paris Peace Conference to consider Chinese claims to Shandong (May-June). On a truly global scale, Britain faced "boiling labor unrest from Winnipeg to Bombay." 43 Amid this global crisis of colonialism, the Bolsheviks were inciting nationalists to democracy, throwing into sharp relief the obduracy of the imperial governments conferring in Paris: Egyptian and Persian delegations, the Bengali polymath Rabindranath Tagore, Indian, Korean and Vietnamese nationalists, Chinese petitioners for Japaneseoccupied Shandong - all were spurned or denied access to the table.

For the future understanding of socialist revolution, this brought a profound shift in the operative geopolitical imaginary. If the October Revolution and its aftermath proved the crucible of a new voluntarism, surpassing the old Kautskian determinism in a strategically driven commitment to making the revolution now, then the convergent crisis of European colonial order gave this a compellingly global dimension. From that same crucible, in other words, came the emergent activism of democratic, communist and radical-nationalist anti-colonial movements in the extra-European world. Across many parts of the globe, but especially in Asia from Persia to Japan, the years I919-22 saw a fascinating conjunction of socialist, anarchist, indigenous and Enlightenment-influenced thinking about self-determination and self-rule, whose terms shaped the coordinates of Third World revolutionary thinking through the I930s and I940s into the era of Bandung.

43 Adam Tooze, The Deluge: The Great War, America, and the Remaking of the Global Order, 1916-1931 (New York: Viking, 20I4), 374. 
In these terms M. N. Roy was hardly the sole South Asian revolutionary to be formed by a pilgrimage along the global circuitry of early twentiethcentury radical thought. We might add the student-journalist Mandayam Parthasarathi Tirumal Acharya (I887-195I), for example, who from the early I90os was experimenting with socialist and nationalist ideas from his refuge in the French enclave of Pondicherry, before traveling to London by way of Marseille and Paris in 1907. Intensely active in both public and clandestine revolutionary nationalist circles, first in London and then from I9Io in Paris, with connections to Turkey and Persia, he spent the war years in Berlin, working through the Berlin Committee for Indian Independence, before moving in December 1918 to Petrograd and thence to Moscow. A delegate to the Second Comintern Congress in July 1920, he passed briefly through the Indian Communist Party in I920-2I, but clashed with Roy, and by I92I was back in Berlin as an anarchosyndicalist. The founding circles of Indian communism disclosed many such stories - the Bengali journalist Muzaffar ("Kakababu") Ahmed (I889-1973), for instance, or the Bombay/Mumbai student Shripad Amrit Dange (I899-199I), or the upper-caste Hindu Abani Mukherji (I89I-1937), who was radicalized into socialism by sojourns in Germany and Japan in 1913-15. Each of these trajectories hinged on the European encounter, as inspiration, repulsion, and spur. ${ }^{44}$

When the very firm structures of Second International thought and practice became unlocked during $1905-17$ - patterns and routines themselves embedded in the previously stable systems of parliamentary constitutionalism and associated political liberties that coalesced in Europe after the I86os there followed a turbulent period of regroupment, whose outcomes long remained unclear. The richness of the indeterminacies came from the gargantuan global consequences of World War I - not just the impact of the war years themselves, but the long-running dynamics of the territorial-political settlement (from Versailles to Sèvres), the geopolitical aftershocks of imperial dissolution all across Eurasia (from East Central Europe through the Middle East and Central Asia to South Asia, China and Japan), and the equally massive fallout from the Bolshevik Revolution. These transformations of 1917-23 accelerated and redirected the flows of influences, people and ideas already in motion from the prewar decade, when revolutions in Russia, Persia, Turkey, Mexico and China enabled a very different worldwide pattern of movement than before.

44 For one brilliant explication, see Benedict Anderson, The Age of Globalization: Anarchists and the Anticolonial Imagination (London: Verso, 2013). 
For what proved to be a relatively transient historical moment, Bolshevism and the Communist International then offered a framework where remarkably heterogeneous radicalisms could convene, with many different imaginings of what a socialist revolution might be thought to entail. In that sense Moscow was not only "the acropolis of the Communist world," but also a beacon of still-widening nationalist creativity and a Mecca for anticolonial aspiration. ${ }^{45}$ Of course, the moment was fleeting. Notwithstanding Lenin's visionary purpose, which into the ig2os stayed remarkably agile, the strategies and visions of a new revolutionary anti-colonialism drew impetus from the Bolshevik Revolution largely in spite of the Bolsheviks themselves. Once the dust had settled, the latter reverted rapidly enough to earlier Eurocentric assumptions. The meanings of October retracted much of their extra-European, anti-colonial reach. The temporary restabilizing of the mid I920s, internationally and inside the Soviet Union itself, quickly closed down most of that heady openness of possibility. After the initial experiments and excesses of voluntarism in 1917-23, inside the drama of the immediate revolutionary conjuncture, the freeing of revolutionary strategy from the Second International's pre-r9I4 economism became captured by Stalinism and fashioned into a reliable program of instrumentally regulated practice: revolution not as the democratic denouement of the final crisis of capitalism, but as the political resource and weapon of the all-knowing Stalinized communist party. The earlier heterogeneity of the anti-colonial radicalisms became a predictable casualty of this Stalinization, sending the cohorts of intellectuals and militants who initially gathered beneath the Bolshevik standard into widely varying future directions. But from the early I900s to the early I920s, the meanings of "socialist revolution" had opened briefly and dramatically outwards into an unfinished, cosmopolitan and surprisingly deterritorial space.

\section{Bibliographical Essay}

The opening chapters of Archie Brown, The Rise and Fall of Communism (London: Bodley Head, 2009), 9-39, and David Priestland, The Red Flag:

45 I take the quoted phrase from Kris Manjapra, Age of Entanglement: German and Indian Intellectuals across Empire (Cambridge, MA: Harvard University Press, 20I4), I80. For another study complicating the dynamics joining the civic, anti-imperial and socialist impulses toward democratic rebellion in the extra-European worlds, see Michelle U. Campos, Ottoman Brothers: Muslims, Christians, and Jews in Early Twentieth-Century Palestine (Stanford: Stanford University Press, 2010). 
A History of Communism (New York: Grove Press, 2009), 16-I02, provide helpful introductions. For the political thinking of Karl Marx and Friedrich Engels in their own time, see George Lichtheim, Marxism: An Historical and Critical Study (London: Routledge \& Kegan Paul, 196I), along with Richard N. Hunt, The Political Ideas of Marx and Engels, vol. II, Classical Marxism, 1850-1895 (Pittsburgh: University of Pittsburgh Press, 1984), and several of the essays in Eric Hobsbawm, How to Change the World: Reflections on Marx and Marxism (New Haven: Yale University Press, 20II), especially the following: "Marx, Engels and Politics" (48-88); "On the Communist Manifesto" (IOI-20); "The Fortunes of Marx's and Engels' Writings" (I76-96); and "The Influence of Marxism I889-19I4" (2II-60). For the debates among German Social Democrats, see Dick Geary, Karl Kautsky (Manchester: Manchester University Press, 1987); Peter Gay, The Dilemmas of Democratic Socialism: Eduard Bernstein's Challenge to Marx (New York: Columbia University Press, 1952); and Henry Tudor and J. M. Tudor (eds.), Marxism and Social Democracy: The Revisionist Debate 1896-1898 (Cambridge: Cambridge University Press, 1988). For French socialism, see Robert Stuart, Marxism at Work: Ideology, Class and French Socialism During the Third Republic (Cambridge: Cambridge University Press, 1992). For the general context, see James Joll, The Second International 1889-1914 (New York: Routledge, 1966). Global dimensions are treated by Kevin B. Anderson, Marx at the Margins: On Nationalism, Ethnicity, and Non-Western Societies (Chicago: University of Chicago Press, 2010), while Marcel van der Linden and Jürgen Rojahn (eds.), The Formation of Labour Movements 1870-1914: An International Perspective, 2 vols. (Leiden: Brill, 1990), offer comprehensive coverage. Pankaj Mishra, From the Ruins of Empire: The Revolt Against the West and the Remaking of Asia (New York: Picador, 2012), surveys the global moment of anti-colonial rebellion in 1919. Together, Helmut Gruber, International Communism in the Era of Lenin: A Documentary History (New York: Anchor Books, 1972), and Jon Jacobson, When the Soviet Union Entered World Politics (Berkeley: University of California Press, 1994), are an excellent introduction. Perry Anderson, Considerations on Western Marxism (London: Verso, 1976), remains a brilliant general conspectus. For the overall context, see Geoff Eley, Forging Democracy: The History of the Left in Europe, 1850-2000 (New York: Oxford University Press, 2002), especially 3-229. 